\title{
Heavy Metals Accumulation in Leaves of Five Plant Species as a Bioindicator of Steel Factory Pollution and their Effects on Pigment Content
}

\author{
Zhian Salih*, Farhad Aziz \\ Environmental Sciences Department, College of Science, Salahaddin University-Erbil, Iraq
}

Received: 30 August 2018

Accepted: 30 October 2018

\begin{abstract}
The present study was carried out to evaluate the effects of heavy metals resulting from steel factories and their impact on contents pigments in five plant species (Olea europaea L., Eucalyptus amygdalina, Nerium oleander L., Dodonaea viscosa, and Phragmites australis) in the city of Erbil. $\mathrm{Fe}, \mathrm{Cu}, \mathrm{Mn}, \mathrm{Ni}, \mathrm{Zn}$, $\mathrm{As}, \mathrm{Pb}, \mathrm{Co}$, chlorophyll a, chlorophyll b, total chlorophyll, carotenoids and total protein were determined in leaves of plants away from the factory used as control (unpolluted site), and plants grown in the garden inside the steel factory (polluted site). The results revealed the significant higher accumulation of all heavy metals in all polluted plants in comparison with unpolluted plants. Higher concentrations of $\mathrm{Fe}, \mathrm{Zn}, \mathrm{As}, \mathrm{Pb}$ and $\mathrm{Co}$ were recorded in leaves of Dodonaea viscosa, while Olea europaea $\mathrm{L}$. found an accumulation of more concentration of $\mathrm{Cu}$ and $\mathrm{Ni}$. The level of $\mathrm{Mn}$ is significantly higher in the leaves of Eucalyptus amygdalina when compared with other plants. Plants grown on contaminated sites showed the lower concentration of pigments and protein contents. A negative correlation was found between the concentration of heavy metals, pigments and total protein contents in all plant species.
\end{abstract}

Keywords: steel factory; air pollution; heavy metals; bioindicator; photosynthetic pigments

\section{Introduction}

Today environmental pollution could be related mainly to industrial development, increasing population and urbanization $[1,2]$. Air pollution is the emission of substances into the atmosphere in quantities that would change its natural composition that is almost causing harm, or discomfort to living things and damage the environment [3].

*e-mail: zhian.salih@su.edu.krd
Anthropogenic activities such as steel and iron industry, mining, smelting procedures, traffic, and agricultural activities are the most important sources of heavy metals in the environment [4]. The infection via heavy metals in plant life is one of the crucial troubles to be faced and requires more interest because heavy metals above their normal ranges are highly threatening to plants and animals [5].

There is no chemical or mechanical device that might ultimately manage the emissions of air pollutants at the supply. The role of plants in pollution has been more recognized in recent years. Once the contaminants are discharged into the atmosphere, the plants uptake the pollutants by sorb and metabolize them from 
the environment [6]. Plants act as filters to reduce air pollution produced from the industrial factory and also as bioindicators of air quality [7].

The concentration of metal in the leaf of woody and herbaceous plants growing near emission sources reflects the degree of pollution in these areas [8]. Also, industrial and mining activities have caused more accumulation of heavy metals ( $\mathrm{Fe}, \mathrm{Zn}, \mathrm{Cu}, \mathrm{Cd}$ and $\mathrm{Pb}$ ) in different plant species [9]. Some of these metals have an unknown biological function, such as $\mathrm{Cd}, \mathrm{Pb}$, and $\mathrm{Hg}$, while others are micronutrients necessary for plant growth, such as $\mathrm{Zn}, \mathrm{Cu}, \mathrm{Mn}, \mathrm{Ni}$, and Co [10].

Leaves are the perfect indicator of air pollution. Most of the particulate matters are deposited on the upper surface of the leaves. One of the maximum vital dangerous outcomes of air pollution is the slow disappearance of chlorophyll and yellowing of leaves, which can be associated with a lowering in the potential for photosynthesis [11]. Reduction in chlorophyll $a$ and $b$ along with the carotenoid from the polluted area was observed when compared with un- or less-polluted regions in leaves of different plant species [12]. A reduction in chlorophyll and protein components of the leaves of plant species (Shorea and Acacia) had been recorded in the polluted industrial region when compared with control (uncontaminated area) [13].
This study was carried out on plants grown in the garden of the steel factory on the Erbil-Gwer main Road, about $22 \mathrm{~km}$ from Erbil city centre. The aim of the present study is to evaluate the effects of accumulated heavy metals $\mathrm{Fe}, \mathrm{Cu}, \mathrm{Mn}, \mathrm{Ni}, \mathrm{Zn}, \mathrm{As}$, $\mathrm{Pb}$ and $\mathrm{Co}$ on pigments and total protein contents of the five plant species Olea europaea L., Eucalyptus amygdalina, Nerium oleander L., Dodonaea viscosa, and Phragmites australis, and compare them with control plants grown in the field of a mountainous area that is naturally grown.

\section{Materials and Methods}

\section{Study Site}

In the present study, two different study sites were selected. The first site was an unpolluted mountain area within Akre district located about $143 \mathrm{~km}$ from Erbil steel factory and situated between $36^{\circ} 44^{\prime} 27.90^{\prime \prime} \mathrm{N}$ longitude and $43^{\circ} 52^{\prime} 51.11^{\prime \prime} \mathrm{E}$ at $675 \mathrm{~m}$ elevation at sea level. The second site was a highly polluted area located inside Erbil steel factory. The factory is located near Lajan and Turjan villages on the main road of Gwer, southwest and about $22 \mathrm{~km}$ from Erbil city, situated between $36^{\circ} 08^{\prime} 18.55^{\prime \prime} \mathrm{N}$ longitude and $43^{\circ} 47^{\prime} 49.68^{\prime \prime} \mathrm{E}$, and $347 \mathrm{~m}$ above sea level (Fig. 1).

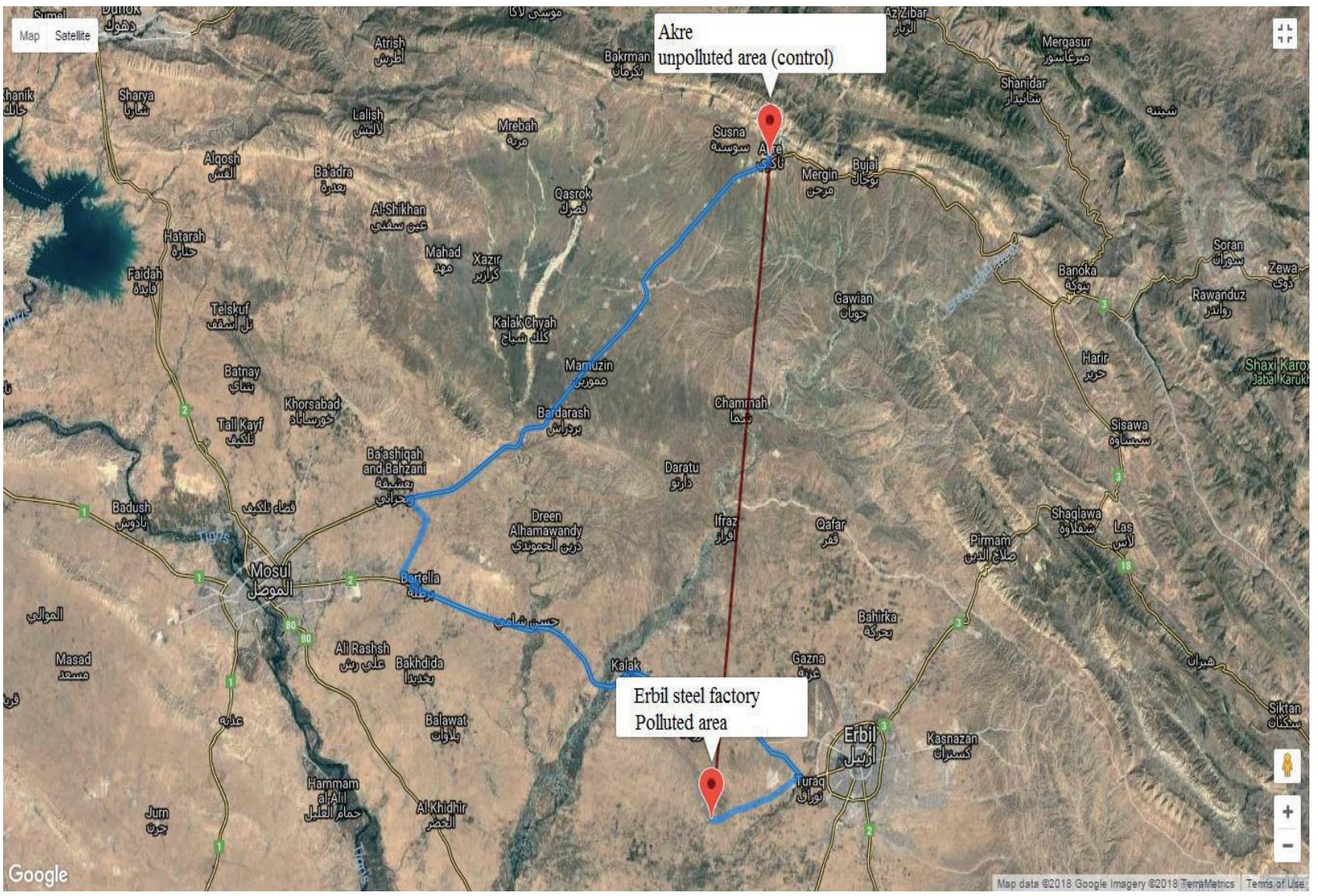

Fig. 1. The map of two studied sites. Control site (unpolluted site of Akre) and polluted site (Erbil steel factory). 


\section{Plant Sampling and Analysis}

This study had been carried out on five selected species of plants: Olea europaea L., Eucalyptus amygdalina, Nerium oleander L., Dodonaea viscosa, and Phragmites australis - all about 4-6 years old. The samples were collected from control and polluted sites in July 2016. Three samples from healthy and mature leaves of each plant were excised with clean scissors from different sides of a small lower branch from the apical bud and were placed in labelled plastic bags and then brought to the laboratory for analysis of various biochemical parameters.

For determining heavy metals concentrations of $\mathrm{Fe}$, $\mathrm{Cu}, \mathrm{Mn}, \mathrm{Ni}, \mathrm{Zn}, \mathrm{As}, \mathrm{Pb}$, and $\mathrm{Co}$ in plant leaves, leaf samples were oven-dried at $70^{\circ} \mathrm{C}$ for $48 \mathrm{hrs}$., crushed, homogenized and sieved at $200 \mu \mathrm{m}$ particle sizes. The powdered samples were analyzed by XRF (x-ray fluorescence spectrophotometer) sky Instrument Genius. XRF analyses were carried out at the laboratory of the Agriculture College, the University of Salahaddin, using a handheld thermal scientific Genius 9000 XRF [14]. The photosynthetic pigments (chlorophyll $a$, chlorophyll $b$ and carotenoids) were estimated by the spectrophotometric method recommended by [15]. The total chlorophyll content was obtained by summation of chlorophyll $a$ and chlorophyll $b$. Total nitrogen was determined by the Kjeldahl method [16]. Total protein was calculated by multiplying total nitrogen by a factor of 6.25 [17].

Statistical analysis of the data was performed using SPSS (Version 17). Results were expressed as means \pm standard error. Independent $t$-test was used for comparison of heavy metals concentration in plant leaves, pigments and total protein contents between the unpolluted site and contaminated site for each plant species. Analysis of variance (ANOVA) and Duncan post-hoc test were applied for comparison of the studied parameters between the studied plant species. Pearson correlation was used for founding the relationships between heavy metals, pigments and total protein. $\mathrm{P} \leq 0.05$ was considered to be statistically significant.

\section{Results and Discussion}

\section{Heavy Metals Content}

Table 1 shows the contents of $\mathrm{Fe}, \mathrm{Cu}, \mathrm{Mn}, \mathrm{Ni}, \mathrm{Zn}, \mathrm{As}$, $\mathrm{Pb}$, and $\mathrm{Co}$ in leaves of (Olea europaea L., Eucalyptus amygdalina, Nerium oleander L., Dodonaea viscosa, and Phragmites australis) in both control sites of the Akre region and the polluted site of a steel factory. The results showed that the leaf concentration contents of metals in the contaminated site were significantly higher than that of the control site in all plant species.

Table 2 shows the post-hoc Duncan-test for founding the comparison of the heavy concentration of five plant species. The significantly higher levels of $\mathrm{Fe}, \mathrm{Zn}$,

\begin{tabular}{|c|c|c|c|c|c|c|c|}
\hline \multirow{2}{*}{$8 \underset{8}{\stackrel{D 00}{50}}$} & 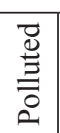 & 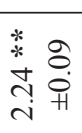 & 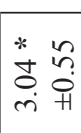 & 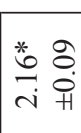 & 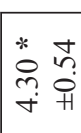 & 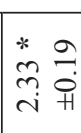 & 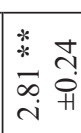 \\
\hline & 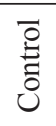 & 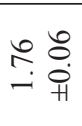 & 용 & 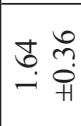 & $\vec{b} \stackrel{n}{n}$ & in & in \\
\hline \multirow{2}{*}{ 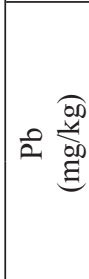 } & 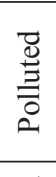 & 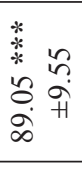 & 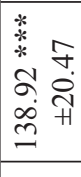 & 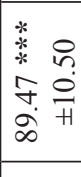 & 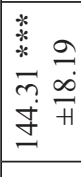 & 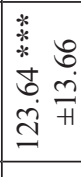 & 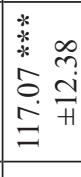 \\
\hline & 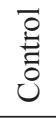 & $\begin{array}{ll}\vec{\infty} & \bar{n} \\
\infty & 0 \\
i & 0\end{array}$ & 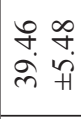 & 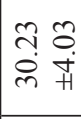 & 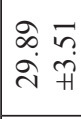 & 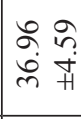 & \begin{tabular}{ll} 
& \multicolumn{2}{c}{} \\
$\dot{m}$ & $\overrightarrow{+}$
\end{tabular} \\
\hline \multirow{2}{*}{ \& } & 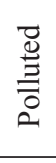 & 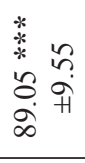 & 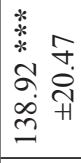 & 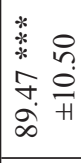 & 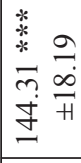 & 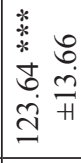 & 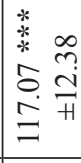 \\
\hline & $\begin{array}{l}\overrightarrow{0} \\
\text { 音 } \\
\text { U }\end{array}$ & $\begin{array}{ll}\bar{\infty} & \bar{n} \\
\infty & \overline{0} \\
\infty & 0 \\
0\end{array}$ & 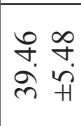 & 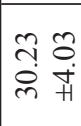 & $\mid \begin{array}{lc}\infty & \vec{n} \\
0 & \vec{H}\end{array}$ & 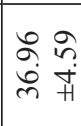 & $\begin{array}{l}\hat{0} \\
\dot{m} \\
\dot{m}\end{array}$ \\
\hline \multirow{4}{*}{ 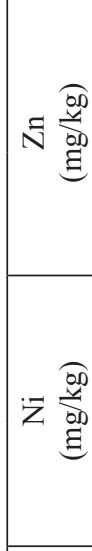 } & $\begin{array}{l}\overline{0} \\
\frac{0}{3} \\
0 \\
0\end{array}$ & 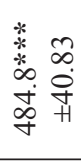 & 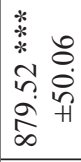 & 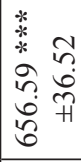 & 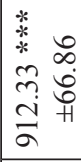 & 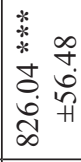 & 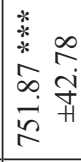 \\
\hline & $\begin{array}{l}\overline{0} \\
\text { 音 } \\
0 \\
\end{array}$ & $\begin{array}{l}\vec{B} \\
\dot{m} \\
\dot{m}\end{array}$ & 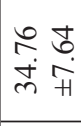 & 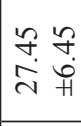 & 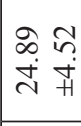 & $\mid \begin{array}{ll}\infty & 0 \\
\infty & 0 \\
\dot{\gamma} & 0 \\
\end{array}$ & $\begin{array}{ll}\tilde{m} & \cdots \\
m & n \\
m & n\end{array}$ \\
\hline & $\begin{array}{l}\vec{D} \\
\stackrel{\Xi}{\Xi} \\
\overline{0} \\
2\end{array}$ & 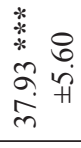 & 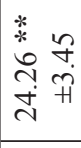 & 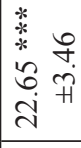 & 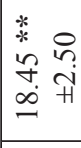 & 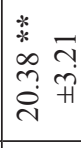 & 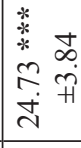 \\
\hline & $\begin{array}{l}\overline{0} \\
\text { 吾 } \\
0\end{array}$ & 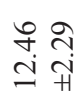 & 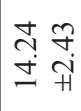 & 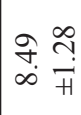 & 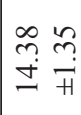 & $\begin{array}{ll}\vec{i} & 0 \\
\stackrel{0}{0} & \vec{H}\end{array}$ & $\begin{array}{ll}2 & 8 \\
0 & \text { i } \\
& \text { i }\end{array}$ \\
\hline \multirow[t]{2}{*}{$\sum \frac{\widehat{D D}}{\mathrm{D}}$} & $\begin{array}{l}\stackrel{\overrightarrow{0}}{\Xi} \\
\overline{0} \\
\stackrel{0}{0}\end{array}$ & 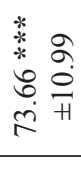 & 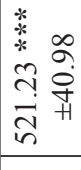 & $\begin{array}{ll}* & 0 \\
* & 0 \\
\infty & 0 \\
0 & 0 \\
\dot{\sigma} & +1\end{array}$ & 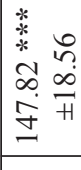 & 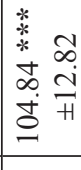 & 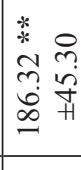 \\
\hline & $\begin{array}{l}\text { Dे } \\
\text { 产 }\end{array}$ & 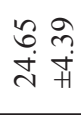 & $\begin{array}{l}R \\
i \\
\dot{i} \\
\dot{i}\end{array}$ & 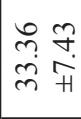 & 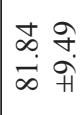 & 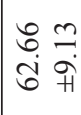 & $\begin{array}{l}\dot{J} \\
\dot{f} \\
\dot{f}\end{array}$ \\
\hline \multirow{2}{*}{ 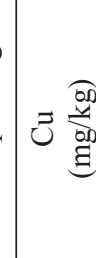 } & 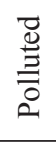 & 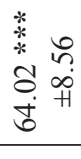 & 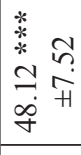 & 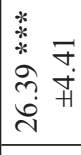 & 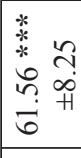 & 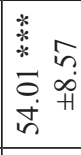 & 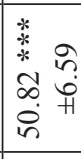 \\
\hline & $\begin{array}{l}\overline{0} \\
\text { 吾 } \\
\text { i }\end{array}$ & 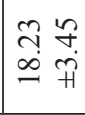 & 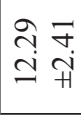 & 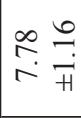 & 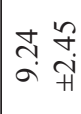 & 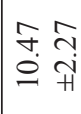 & 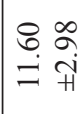 \\
\hline \multirow{2}{*}{ I } & 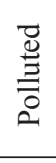 & 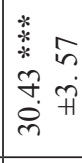 & 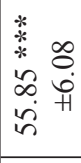 & 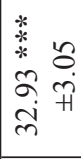 & 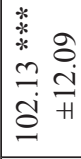 & 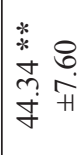 & 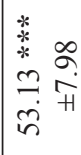 \\
\hline & 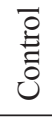 & 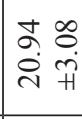 & $\begin{array}{ll}8 & 8 \\
\dot{\lambda} & + \\
\end{array}$ & $\begin{array}{l}\text { 竎 } \\
\text { in } \\
\text { in }\end{array}$ & $\begin{array}{ll}2 & 0 \\
\hat{i} & 0 \\
i & +\end{array}$ & $\mid \begin{array}{ll}\infty & 8 \\
\dot{\sim} & \stackrel{+}{+}\end{array}$ & 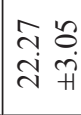 \\
\hline$\frac{\tilde{\Xi}}{2}$ & & 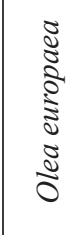 & 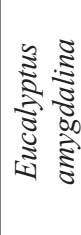 & 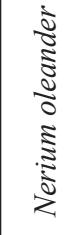 & 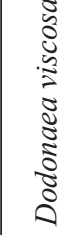 & 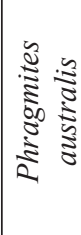 & $\begin{array}{l}\bar{\sigma} \\
0\end{array}$ \\
\hline
\end{tabular}




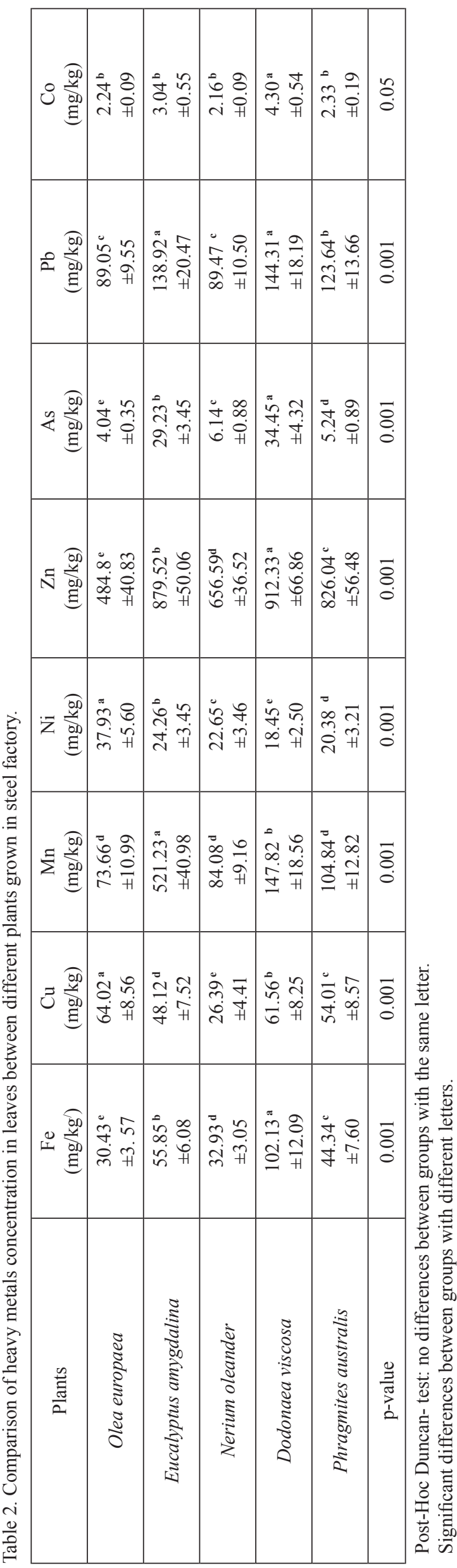

$\mathrm{As}, \mathrm{Pb}$ and $\mathrm{Co}$ were recorded in leaves of Dodonaea viscosa, while Olea europaea reported an accumulation of more concentration of $\mathrm{Cu}$ and Ni. The level of $\mathrm{Mn}$ is significantly higher in the leaves of Eucalyptus amygdalina when compared with other plants. The accumulation of $\mathrm{Fe}, \mathrm{Mn}, \mathrm{Zn}, \mathrm{As}$ and $\mathrm{Pb}$ is lower in Olea europaea, as well as Nerium oleander showing the lower concentrations of $\mathrm{Cu}$ and $\mathrm{Co}$. Lower $\mathrm{Ni}$ contents were observed in Dodonaea viscosa. These results are in agreement with the findings of the previous study, who found an increase in accumulation of heavy metals in leaves of Nerium and Phragmites plants in the pollution site when compared with the non-polluted site [18].

Plants growing near industrial regions display the multiplied awareness of heavy metals, serving in many cases as biomonitors of pollution. Plants take up massive quantities of pollutants and translocate them into vegetative and generative tissues [19], indicating the environmental quality. Airborne toxins can aggregate on leaf surfaces, and a few components could enter using the stomata and gather in leaf tissues [20]. Some of these heavy metals (i.e., $\mathrm{Mn}, \mathrm{Cu}, \mathrm{Ni}, \mathrm{Zn}$, and $\mathrm{Co}$ ) are necessary for plant growth and may correct nutritional deficiencies, and high concentrations of these metals can negatively affect the physiological functions of growing plants [21] and cause high risks for humans and the environment. Iron is one of the essential mineral nutrients required for several physiological processes in plants. The standard concentration content of iron in plants is necessary both for plants health and for a nutrient source to man and animals [22]. The toxic concentration of plants is (300 ppm) [23], and in our studied plants $\mathrm{Fe}$ concentrations did not reach toxic levels.

Natural copper content in plants varies in the range of $1-20 \mathrm{mg} / \mathrm{kg}$ [24]. Copper content in a leaf of all studied plant species in control site is under the limit value, but it is higher than the limit value in the contaminated location, and the most senior concentration observed in Olea europaena $(64.02 \mathrm{mg} / \mathrm{kg})$. The same results were obtained by [25] and [26], who observed a toxic concentration of copper in an industrial area in different plant species. Also, the highest levels of $\mathrm{Mn}$ and $\mathrm{Pb}$ after $\mathrm{Zn}$ in our study were found in the polluted site with a maximum value of $\mathrm{Mn}$ recorded in Eucalyptus amygdalina $(521.23 \mathrm{mg} / \mathrm{kg}$ ) and $\mathrm{Pb}$ in Dodonaea viscosa $(144.31 \mathrm{mg} / \mathrm{kg})$.

Mn concentrations 73.66, 521.23, 84.08, 147.82 and $104.84 \mathrm{mg} / \mathrm{kg}$ in Olea europaea L., Eucalyptus amygdalina, Nerium oleander L., Dodonaea viscosa, and Phragmites australis respectively can be considered high in plants. The concentrations of $\mathrm{Mn}$ in all plant species in the polluted site had been higher than the threshold micronutrient concentration in animal feeds of more than $70 \mathrm{mg} / \mathrm{kg}$, [24], but in control, the site is under the limited value.

Nickel plays a vital role in metabolic processes of higher plants [27], with the value of nickel in all studied plants in the polluted site reaching: Olea europaea L., 
Eucalyptus amygdalina, Nerium oleander L., Dodonaea viscosa, and Phragmites australis was 37.93, 24.26, $22.65,18.45$ and $20.38 \mathrm{mg} / \mathrm{kg}$, respectively. These values were high and toxic as compared to the environmental standard range $1-5 \mathrm{mg} / \mathrm{kg}$ [27].

In the present study, comparison of all metals in the polluted site showed that the concentration of zinc is the highest, with the average highest value detected in Dodonaea viscosa $(912.33 \mathrm{mg} / \mathrm{kg})$. The environmental pollution of $\mathrm{Zn}$ dramatically influences the levels of this metal in plants [20]. Zinc is an essential element for plants, but when their concentration become toxic it produces varied physiological and biochemical changes in plants. A toxic concentration of $\mathrm{Zn}$ for a plant is about $300-400 \mathrm{mg} / \mathrm{kg}$ depending on plant species [28]. According to these values, the sampling locations for $\mathrm{Zn}$ concentrations found in our study in the control site in all plant species are smaller than the toxic limits, but the concentration of $\mathrm{Zn}$ in contaminated place inside steel factory and all plant species is above the toxic range. Therefore, it can be supposed that all plant species are strongly affected by pollutants produced from the factory.

The arsenate concentration in Eucalyptus 29.23 and Dodonaea $34.45 \mathrm{mg} / \mathrm{kg}$ in the polluted site was above the toxicity threshold $3-10 \mathrm{mg} / \mathrm{kg}$ for plants (Moreno-Jiménez). All plant species in the control site in addition to Olea, Nerium, and Phragmites in the contaminated site showed normal and under threshold values of arsenate. Lead is one of the most abundant heavy metals, and its toxic effects cause environmental and health problems [29]. The primary source of lead pollution is human activities, mainly referring to lead emissions from industry and transportation, a waste product of vehicles, and effluents from storage batteries. Today, the major sources of lead emissions to the environment are from the process of mining [30]. Our results observed significant differences in lead concentration between control and the contaminated region. Maximum lead content is $144.31 \mathrm{mg} / \mathrm{kg}$, found in Dodonaea, and the lowest level is $89.05 \mathrm{mg} / \mathrm{kg}$ found in Olea, whose results are in agreement with the results of [31] and [32], who observed a higher concentration of lead in plants in the polluted site when compared with plants found in unpolluted places. The concentration of lead in all plant samples in our study is higher than the standard value of $5-10 \mathrm{mg} / \mathrm{kg}$, according to WHO permissible limits [33]. The concentration of lead in the polluted site is more than 10 times the standard value, indicating that steel factories profoundly affect plant species grown near them.

Cobalt is necessary for healthy growth of plants and animals, but is toxic at elevated concentrations. The body needs only a trace amount of it. The concentration range of Cobalt in all plant samples in the polluted site is $(2.24$ to $4.30 \mathrm{mg} / \mathrm{kg})$, and in the control site is $(1.40$ to $1.76 \mathrm{mg} / \mathrm{kg}$ ). Cobalt value in a contaminated site is two times more than the control site, but is lower than the toxic level $10 \mathrm{mg} / \mathrm{kg}$ in plants.

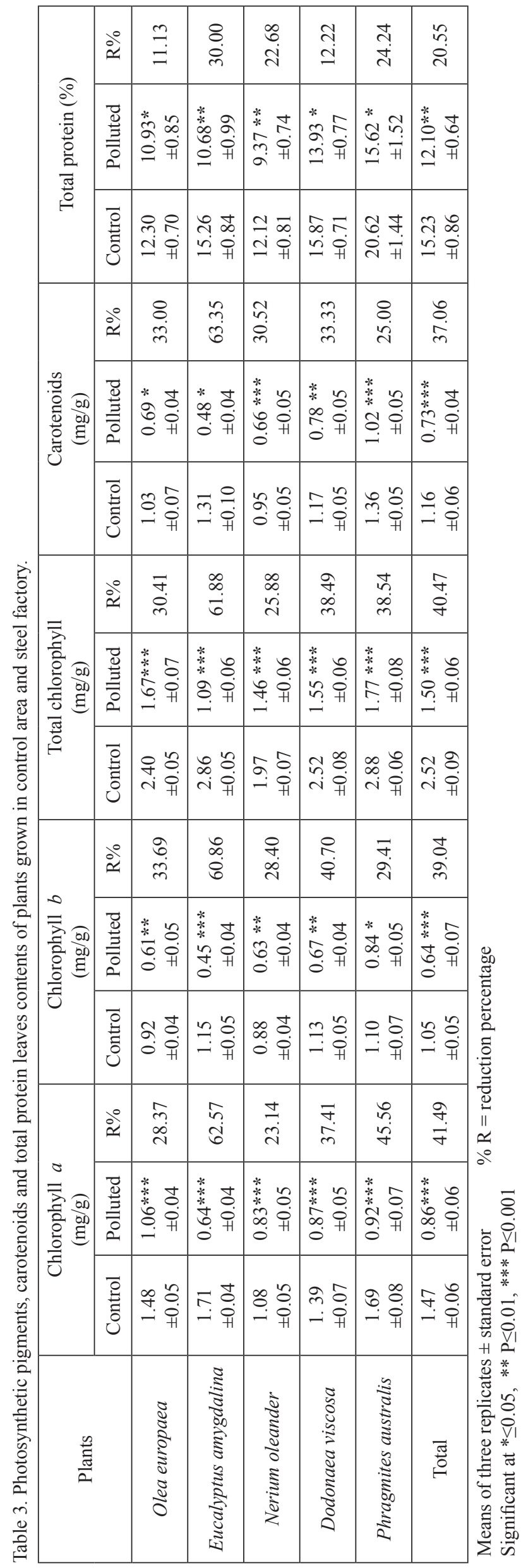


Table 4. Comparison of photosynthetic pigments and total protein contents between different plants in polluted site.

\begin{tabular}{|c|c|c|c|c|c|}
\hline Plants & $\begin{array}{c}\text { Chlorophyll } a \\
(\mathrm{mg} / \mathrm{g})\end{array}$ & $\begin{array}{c}\text { Chlorophyll } b \\
(\mathrm{mg} / \mathrm{g})\end{array}$ & $\begin{array}{l}\text { Total chlorophyll } \\
(\mathrm{mg} / \mathrm{g})\end{array}$ & $\begin{array}{l}\text { Carotenoids } \\
(\mathrm{mg} / \mathrm{g})\end{array}$ & $\begin{array}{c}\text { Total protein } \\
(\%)\end{array}$ \\
\hline Olea europaea & $1.06 \pm 0.04^{\mathrm{a}}$ & $0.61 \pm 0.05^{\mathrm{b}}$ & $1.67 \pm 0.07^{\mathrm{b}}$ & $0.69 \pm 0.04^{\text {bc }}$ & $10.93 \pm 0.8^{c}$ \\
\hline Eucalyptus amygdalina & $0.64 \pm 0.04^{\mathrm{d}}$ & $0.45 \pm 0.04^{\mathrm{c}}$ & $1.09 \pm 0.06^{\mathrm{e}}$ & $0.48 \pm 0.04^{\mathrm{d}}$ & $10.68 \pm 0.99^{\mathrm{c}}$ \\
\hline Nerium oleander & $0.83 \pm 0.05^{\mathrm{bc}}$ & $0.63 \pm 0.04^{b}$ & $1.46 \pm 0.06^{\mathrm{d}}$ & $0.66 \pm 0.05^{\mathrm{c}}$ & $9.37 \pm 0.74^{c}$ \\
\hline Dodonaea viscosa & $0.87 \pm 0.05^{\mathrm{b}}$ & $0.67 \pm 0.04^{\mathrm{b}}$ & $1.55 \pm 0.06^{\mathrm{c}}$ & $0.78 \pm 0.05^{b}$ & $13.93 \pm 0.77^{b}$ \\
\hline Phragmites australis & $0.92 \pm 0.07^{\mathbf{b}}$ & $0.84 \pm 0.05^{\mathrm{a}}$ & $1.77 \pm 0.08^{\mathrm{a}}$ & $1.02 \pm 0.05^{\mathrm{a}}$ & $15.62 \pm 1.52^{a}$ \\
\hline p-value & 0.001 & 0.001 & 0.001 & 0.001 & 0.001 \\
\hline
\end{tabular}

Post-Hoc Duncan- test: no differences between groups with the same letter.

Significant differences between groups with different letters

\section{Photosynthetic Pigments and Total Protein Content}

When plants are exposed to environmental pollution above the normal physiologically acceptable range, photosynthesis gets deactivated [34]. Hence any alteration in chlorophyll concentration may change the morphological, physiological and biochemical processes of the plant. Green plants have always played a role in determining the quality of the environment. Many green plants act as environmental biomarkers and mitigators of pollutants [35].

The results in Table 3 show that the pigments chlorophyll $a$, chlorophyll $b$, total chlorophyll, carotenoids and total protein contents in leaves of studied plants Olea europaea, Eucalyptus amygdalina, Nerium oleander, Dodonaea viscosa, and Phragmites australis are significantly lower in polluted sites in comparison to the control site. The highest percentage reduction of chlorophyll $a(62.57 \%)$, chlorophyll $b$ $(60.86 \%)$, total chlorophyll $(61.88 \%)$, carotenoids $(63.35 \%)$ and total protein $(30.00 \%)$ were reported in Eucalyptus amygdalina. The lower reduction percentage of chlorophyll a (23.14\%), chlorophyll b $(28.40 \%)$ and total chlorophyll (25.88\%) were observed in Nerium oleander, while lower carotenoids $(25.00 \%)$ and total protein $(11.13 \%)$ reduction percentages were recorded in Phragmites australis and Olea europaea respectively.
Table 4 shows the post hoc Duncan-test for founding the comparison of photosynthetic pigments and total protein among all plant species. The leaves of Phragmites australis showed the significantly higher concentration of total chlorophyll, carotenoids and protein when compared with other plant species, while Eucalyptus amygdalina recorded a lower level of all pigments in leaves. A lower concentration of protein contents was observed in Nerium oleander. Metal-specific effects on chlorophyll and carotenoid biosynthesis, leaf structure, plant species and the amounts of accumulated metals cause the different responses of photosynthetic pigments [36].

The results of our finding are in agreement with the observations of another study, [13], that showed a significant decrease in chlorophyll and protein contents in two plant species in industrial air pollution site when compared with the unpolluted site. Heavy metals effluent from steel factory caused a reduction in chlorophyll contents in Phaseolus mungo [37]. The same results are obtained with [12] in different plant species such as Nerium, Ficus and Mangifera. These results indicated that airborne heavy metals caused reductions of pigment content via alteration of chloroplast structure and thylakoid membrane composition [38].

In the present study, decreasing pigment contents in parallel with increasing pollution levels were detected. As shown in Table 5, a significant negative correlation was observed between ( $\mathrm{Fe}, \mathrm{Cu}, \mathrm{Mn}, \mathrm{Ni}, \mathrm{Zn}, \mathrm{As}, \mathrm{Pb}$,

Table 5. Pearson correlation (r) between photosynthetic pigments, carotenoids, total protein and heavy metals in leaves of studied plants.

\begin{tabular}{|c|c|c|c|c|c|c|c|c|}
\hline & $\mathrm{Fe}$ & $\mathrm{Cu}$ & $\mathrm{Mn}$ & $\mathrm{Ni}$ & $\mathrm{Zn}$ & $\mathrm{As}$ & $\mathrm{Pb}$ & $\mathrm{Co}$ \\
\hline Chlorophyll $a$ & $-0.586^{* *}$ & $-0.678^{* *}$ & $-0.625^{* *}$ & $-0.522^{* *}$ & $-0.855^{* *}$ & $-0.612^{* *}$ & $-0.815^{* *}$ & $-0.604^{* *}$ \\
\hline Chlorophyll $b$ & $-0.534 * *$ & $-0.723^{* *}$ & $-0.621^{* *}$ & $-0.672 * *$ & $-0.783 * *$ & $-0.603 * *$ & $-0.758^{* *}$ & $-0.622^{* *}$ \\
\hline Total Chlorophyll & $-0.584 * *$ & $-0.719 * *$ & $-0.644 *$ & $-0.602 * *$ & $-0.852 * *$ & $-0.629 * *$ & $-0.817 * *$ & $-0.631 * *$ \\
\hline Carotenoids & $-0.471 * *$ & $-0.641 * *$ & $-0.621 * *$ & $-0.645^{* *}$ & $-0.717 * *$ & $-0.574 *$ & $-0.684 * *$ & $-0.579 * *$ \\
\hline Total protein & -0.132 & -0.297 & -0.259 & $-0.472 * *$ & -0.335 & -0.205 & -0.277 & -0.161 \\
\hline
\end{tabular}

*Correlation is significant at 0.05 levels - negative correlation found

**Correlation is significant at 0.01 levels 
Co) and all pigments (chlorophyll $a$, chlorophyll $b$, total chlorophyll, carotenoids). Also, a significant negative correlation was found between $\mathrm{Ni}$ and total protein. Increasing the levels of $\mathrm{Cd}, \mathrm{Hg}$ and $\mathrm{Pb}$ and even low concentrations are toxic to plants and caused the formation of reactive oxygen species, resulting in changing the levels of antioxidants and proteins and decreases in pigment content [39]. Abdelhafez and $\mathrm{Li}$ revealed that heavy metals uptake by the growing plants is a function of soil $\mathrm{pH}$, metal concentrations in soils, types and varieties of plants. Also, they have mentioned that many plant species can metabolise different types of heavy metals based on their physiological performance, whereby plants varied in their ability to uptake and accumulate heavy metals [40]. The possible reason that caused the reduction of protein content in the polluted plant might be the enhanced rate of protein denaturation and also the breakdown of protein to amino acid [41]. Another reason may be raised in the activity of the degradative enzyme like proteases, which catalyze the breakdown of polypeptides into amino acids in order to withstand the stress induced by pollution [42].

Dust particles that arise from industrial processes have a negative impact on the ecosystem and causr reductions in chlorophyll. Higher concentration of $\mathrm{NO}_{2}, \mathrm{SO}_{2}$, and fluoride of heavy metals released from industries reduce growth and photosynthesis in tree species; this may be due to several photochemical reactions such as oxidation, reduction and reversible bleaching of photosynthetic pigments under stressed conditions. Another possible reaction may be due to an alkaline condition build up by the dissolution of chemicals present in dust particles in cell saps, which are responsible for chlorophyll degradation. The deposition of a dust particle in stomata interfere with a gaseous exchange that consequently retards chlorophyll synthesis [43]. Reduction in chlorophyll content usually results in the conversion of chlorophyll into phaeophytin, which arises due to loss of magnesium ions by replacement with two hydrogen atoms [12].

\section{Conclusions}

The results showed that plants grown on the polluted area within a steel factory have a higher concentration of heavy metals than unpolluted areas. A negative correlation was found between the concentration of heavy metals and leaf contents of pigments and protein in all plant species. The results revealed that plants such as Olea europaea, Eucalyptus amygdalina, Nerium oleander, Dodonaea viscosa, and Phragmites australis are good bioindicators and might be used in pollution monitoring studies in industrial areas. Additionally, the studied plants have an accumulation ability used for removing the metal toxicity within the atmosphere close to the polluted region.

\section{Acknowledgements}

The authors are grateful and wish to express thanks to the manager and staff of Erbil steel factory for allowing the collection of the studied plant samples.

\section{Conflict of Interest}

The authors declare no conflict of interest.

\section{References}

1. AGBAIRE P.O., AKPORHONOR E.E., PERETIEMOCLARKE B.O., IPEMU S. Monitoring the air Pollution Tolerance Indices of Plants Around Warri Refinery and Petrochemical Company (WRPC), Delta State Nigeria. Adv Environ Chem Pollut Stud. 1, 179, 2013.

2. JAIN A., KUTTY C.S. Biomonitoring of dust Pollution of Road side of Hardes using Air Pollution Tolerance Index (APTI). Int J P App Biosci. 2, 233, 2014.

3. BEGUM A., HARIKRISHNA S. Evaluation of some tree species to absorb air pollutants in three industrial locations of South Bengaluru, India. Journal of Chemistry. 7, S151, 2010.

4. STIHI C., BANCUTA A., POPESCU I., VIRGOLICI M., CIMPOCA V., GUGIU M., VLAICU G. Air pollution studies using PIXE and ICP Methods. Journal of Physics: Conference Series. 41, 565, 2006.

5. NAZIR R., KHAN M., MASAB M., REHMAN H.U., RAUF N.U., SHAHAB S., AMEER N., SAJED M., ULLAH M., RAFEEQ M. Accumulation of heavy metals $(\mathrm{Ni}, \mathrm{Cu}, \mathrm{Cd}, \mathrm{Cr}, \mathrm{Pb}, \mathrm{Zn}, \mathrm{Fe})$ in the soil, water and plants and analysis of physico-chemical parameters of soil and water collected from Tanda Dam Kohat. Journal of pharmaceutical sciences and research. 7, 89, 2015.

6. SHARMA A., RAI P., TRIPATHI B. Magnetic biomonitoring of roadside tree leaves as a proxy of vehicular pollution. Urban Planing and Environment: Strategies and Challenges, Lakshmi Lakshmi Vyas (Ed), Mc Millan Advanced Research Series. 326, 2007.

7. SALAA M.M., AL-KAWAZ L.S. Assessment of air pollution using air pollution tolerance index (APTI) by two species plant (Conocarpus lancifolius and Dodonaea $v i s \cos a$ ) in babylon provinus. Mesopo Environ j. 3, 11, 2017.

8. AKSOY A., ŞAHIN U., DUMAN F. Robinia pseudoacacia L. as a posssible biomonitor of heavy metal pollution in Kayseri. Turkish Journal of Botany. 24, 279, 2000.

9. DOĞANLAR Z.B., ATMACA M. Influence of airborne pollution on $\mathrm{Cd}, \mathrm{Zn}, \mathrm{Pb}, \mathrm{Cu}$, and $\mathrm{Al}$ accumulation and physiological parameters of plant leaves in Antakya (Turkey). Water, Air, \& Soil Pollution. 214, 509, 2011.

10. GAUR A., ADHOLEYA A. Prospects of arbuscular mycorrhizal fungi in phytoremediation of heavy metal contaminated soils. Current Science. 86, 528, 2004.

11. JOSHI P., SWAMI A. Physiological responses of some tree species under roadside automobile pollution stress around city of Haridwar, India. The Environmentalist. 27, 365, 2007.

12. PIMPLE N.S. Adverse Effect of Air Pollutants on the Chlorophyll Content in Leaves from Pune, 
Maharashtra (India). Int J Pharm Sci Rev Res. 44, 131, 2017.

13. KARMAKAR D., MALIK N., PADHY P.K. Effects of Industrial Air pollution on Biochemical parameters of Shorea robusta and Acacia auriculiformis. Research Journal of Recent Sciences. 2277, 2502, 2016.

14. ENE A., BOSNEAGA A., GEORGESCU L. Determination of heavy metals in soils using XRF technique. Rom Journ Phys. 55, 815, 2010.

15. METZZENER H., RAVA H., SENDER H. Unter suchungen zur synchronis iebekiety pigments mangel von chlrella. Planta. 65, 186, 1965.

16. RYAN J., ESTEFEN G., RASHID A.Soil Chemical Analysis (Organic matter). In Soil and Plant Analysis Laboratory Manual. ICARDA, Aleppo, Syria and NARC, Pakistan, 2001

17. DALALY B.K., AL-HAKIM S.H. Food analysis. Dar Alkutob for printing and publication, University of Mosul, 1987

18. AHMAD A.M. Study of heavy metal accumulation in soil and some plants in Erbil Governorate. M.Sc. Environmental Sciences: Salahaddin University, 46, 2017.

19. ATAABADI M., HOODAJI M., NAJAFI P. Biomonitoring of some heavy metal contaminations from a steel plant by above ground plants tissue. African Journal of Biotechnology. 10, 4127, 2011.

20. SRINIVAS N., RAO S.R., KUMAR K.S. Trace metal accumulation in vegetables grown in industrial and semi-urban areas-a case study. Applied Ecology and Environmental Research. 7, 131, 2009.

21. FENG J., SHI Q., WANG X., WEI M., YANG F., XU H. Silicon supplementation ameliorated the inhibition of photosynthesis and nitrate metabolism by cadmium (Cd) toxicity in Cucumis sativus L. Scientia Horticulturae. 123, $521,2010$.

22. NAGAJYOTI P., LEE K., SREEKANTH T. Heavy metals, occurrence and toxicity for plants: a review. Environmental chemistry letters. 8, 199, 2010.

23. GOWARIKER V., KRISHNAMURTHY V., GOWARIKER S., DHANORKAR M., PARANJAPE K.The Fertilizer Encyclopedia: John Wiley \& Sons, 2009

24. CLEMENTE R., PAREDES C., BERNAL M. A field experiment investigating the effects of olive husk and cow manure on heavy metal availability in a contaminated calcareous soil from Murcia (Spain). Agriculture, ecosystems \& environment. 118, 319, 2007.

25. TAHAR K., KELTOUM B. Effects of heavy metals pollution in soil and plant in the industrial area, West Algeria. Journal of the Korean chemical society. 55, 1018, 2011.

26. OSMANOVIĆ S., HUSEINOVIĆ S., GOLETIĆ Š., ŠABANOVIĆ M., ZAVADLAV S. Accumulation of heavy metals in the fruit and leaves of plum (Prunus domestica L.) in the Tuzla area. Hrana u zdravlju i bolesti: znanstveno-stručni časopis za nutricionizam i dijetetiku. 3, 44, 2014.

27. AHMAD S., ERUM S. Integrated assessment of heavy metals pollution along motorway M-2. Soil and Environment. 29, 110, 2010.

28. BROADLEY M.R., WHITE P.J., HAMMOND J.P., ZELKO I., LUX A. Zinc in plants. New phytologist. 173, 677, 2007.
29. TIWARI S., TRIPATHI I., TIWARI H. Effects of lead on Environment. International Journal of Emerging Research in Management and Technology. 2, 1, 2013.

30. LIN S., WANG X., YU I.T.S., TANG W., MIAO J., LI J., WU S., LIN X. Environmental lead pollution and elevated blood lead levels among children in a rural area of China. American journal of public health. 101, 834, 2011.

31. ASLAM M., VERMA D.K., DHAKERYA R., RAIS S., ALAM M., ANSARI F.A. Bioindicator: A Comparative Study on Uptake and Accumulation of Heavy Metals in Some Plant. Research Journal of Environmental and Earth Sciences. 4, 1060, 2012.

32. HUSSAIN I., KHAN L. Comparative study on heavy metal contents in Taraxacum Officinale. International Journal of Parmacognosy and Phytochemical Research. 2, $15,2010$.

33. WHO.Quality Control Methods for Medicinal Plant Materials. World Health Organization, Geneva, Switzerland, 2005

34. GOVINDARAJU M., GANESHKUMAR R.S., SUGANTHI P., MUTHUKUMARAN V.R., VISVANATHAN P. Impact Assessment of Air Pollution Stress on Plant Species through Biochemical Estimations. International Journal of Environmental and Ecological Engineering. 4, 696, 2010.

35. VERMA V., CHANDRA N. Biochemical and ultrastructural changes in Sida cordifolia L. and Catharanthus roseus L. to auto pollution. International scholarly research notices. 2014, 1, 2014.

36. PANDA S. Heavy-metal phytotoxicity induces oxidative stress in a moss, Taxithellium sp. Current Science. 84, 631, 2003.

37. KUMAR S., VANDANA Detection of Heavy Metals in Steel Factory Effluent and Their Effect on Seed Germination, Seedling Growth, Chlorophyll Contents, Growth and Yield of Phaseolus mungo. International Journal of Applied and Pure Science and Agriculture (IJAPSA). 2, 171, 2016.

38. DEVI CHINMAYEE M., ANU M., MAHESH B., MARY S., MINI I., SWAPNA T. A comparative study of heavy metal accumulation and antioxidant responses in Jatropha curcas. IOSR Journal of Environmental Science, Toxicology and Food Technology. 8, 58, 2014.

39. KIRAN Y., ŞAHIN A. The effects of the lead on the seed germination, root growth, and root tip cell mitotic divisons of Lens culinaris Medik. Gazi University Journal of Science. 18, 17, 2005.

40. ABDELHAFEZ A.A., LI J. Environmental monitoring of heavy metal status and human health risk assessment in the agricultural soils of the Jinxi River area, China. Human and Ecological Risk Assessment: An International Journal. 21, 952, 2015.

41. THAMBAVANI D.S., MAHESWARI J. Response of native tree species to ambient air quality. Chem Sci Transac. 3, 438, 2014.

42. DOHMEN G., KOPPERS A., LANGEBARTELS C. Biochemical response of Norway spruce (Picea abies (L.) Karst.) towards 14-month exposure to ozone and acid mist: effects on amino acid, glutathione and polyamine titers. Environmental Pollution. 64, 375, 1990.

43. GEETA C., NAMRATA C. Effect of air pollution on the photosynthetic pigments of selected plant species along roadsides in Jamshedpur, Jharkhand. Research in Plant Biology. 4, 2014. 